\title{
Towards improving citizens engagement: A review of parliamentary websites in the 36 state legislatures in Nigeria
}

\author{
Abdulsalam Mustafa ${ }^{1 *}$, Mahammad Sharifov ${ }^{2}$ \\ ${ }^{1,2}$ Department of Computer Science, Khazar University, Baku, Azerbaijan
}

\author{
Keywords \\ Citizens participation \\ Legislature \\ Social media \\ State assembly \\ Web tools
}

Received: 20 June 2018

Accepted: 17 July 2018

Published: 9 August 2018

\begin{abstract}
This study investigates the contents of official parliamentary websites in the 36 State Houses of Assembly of Nigeria to determine how they facilitate effective engagement between citizens and their elected representatives. Parliaments represent the interests of citizens and therefore remain critical to democracy and good governance. Therefore, for effective citizens' engagement, ensuring the online presence, and; enhancing the transparency of internal processes, parliaments leverage information and communication technology globally. The methodology includes a manual test based on categories and critical sub-factors in line with Inter-Parliamentary Union (IPU) Guidelines. Desk research was also used to determine technical challenges for the implementation of e-parliament. The findings reveal that $36 \%$ of the state assemblies have official websites. Five are fully functional, and just five state legislatures effectively utilize interactivity tools to re-engage the citizens. Results show that $58 \%$ of the state legislatures use social media tools such as Facebook and Twitter. The authors concluded that in enhancing civic participation, state legislatures need to provide a relatively open, more responsive, accessible, and interactive website while extending medial social tools.
\end{abstract}

(C) 2018 The Author(s). Published by TAF Publishing.

\section{INTRODUCTION}

Legislatures are crucial to good governance around the world. The legislature is regarded as one of the critical state institutions of democracy and plays an essential role in legislation, oversight, and representation (Azhar, 2015; Global Centre for ICT in Parliament, 2016). Their representational role includes ensuring active citizens participation in the policy-making process. However, in some countries, parliaments are still considered as weak, ineffective and marginalized (Edigheji, 2016; Sriboonyaponrat, 2016) and have a low level of civic participation in the decisionmaking process. While E-governance involves the rendering of government services and information to the public using electronic means (Nkwe, 2012), e-parliament involves the effective utilization of Information and Communication Technology (ICT) tools and proficiency by the legislature, for a more open, effective, accountable, efficient and inter- active parliament for enhanced citizens' engagement and better representation of the electorates. Before the revolutionary transformation in communication ushered in the digital age in the late 80s, parliamentary communication to citizens was severely limited and mostly unidirectional because proceedings were mostly published in Hansards and kept in archives for the citizens. Consultations were mainly through face to face which was expensive, time consuming and lacks fidelity. This means that majority, if not all the citizens could not participate in decision making in the parliaments. Essentially, elected representatives could neither connect with the electorates for input or feedbacks nor inform them of constituency activities.

But since the advent of online portal and websites, there have been tremendous advantages. The online portals and websites have imbued parliaments with more purposive methods of communication particularly in the face of

\footnotetext{
* corresponding author: Abdulsalam Mustafa

†email: abdulsalam.mustafa@khazar.org
} 
declining traditional media coverage. Their growing importance also manifests in the rapid increase in visitors to parliamentary sites. Many scholars (Coleman, 2000), have pointed out that the inherent interactivity of the internet enhances parliamentary activities and democratic practice. Internet facilitates information and communication between parliamentarians and their representatives through online platforms. The internet equally offers the required platforms for MPs to quickly and regularly communicate through e-mails with their constituents (Lawyer, 2017; Leston \& Thompson, 2003). The Internet also enables parliamentary websites to provide impartial and unfiltered parliamentary information to constituents and disseminate large amounts of such information at relatively low costs (Nabatchi \& Leighninger, 2015). Furthermore, parliamentary websites enable parliaments to market their image to the public, cheaply, quickly and efficiently (Dai \& Norton, 2007). These features facilitate increase of transparency of parliamentary activities and also aids scrutiny of the legislature (Norris, 2001). With low public trust in elected representatives and parliamentary institutions as a permanent feature (Leston \& Thompson, 2013), parliaments have turned to ICT for enhanced visibility, promoting greater transparency, more effective representation and enhancing citizens' engagement in the democratic process. Websites enable a large amount of up-to-date information on public decision-making to be available to many citizens at a relatively low cost. However, for legislatures to successfully leverage on ICT tools, they need to fully understand how these tools can be effectively used and the primary role of their websites.

This study aims at evaluating the parliamentary websites of Nigeria's 36 State Houses of Assembly, to determine the level of their usage in facilitating communication between citizens and their Members of Parliaments (MP) and evaluating the importance of social media and interactive tools utilized for better citizens' engagement.

\section{LITERATURE REVIEW}

The main aim of a legislative website is to increase online participation with citizens and to achieve this, the websites need to be interactive. Websites also facilitate engagement between citizens and their elected representatives by providing them with details of MPs and the means by which they can interact with their representatives. In recent years, parliaments around the world have enhanced their websites to improve access to legislative information and other parliamentary resources (Alahoul, Azizan, \& Alwi, 2016; Leston \& Thompson, 2013; Salgado, 2016). Sev- eral parliaments use ICT tools such as e-polling, e-petitions, blogs, fora, chat etc. in their online portals, to enhance 'Youth Parliament' programmes (Papaloi, 2011). Innovative features allow constituents and researchers to locate and utilize detailed information on laws and lawmaking in various ways.

These include tracking tools and alerts, apps, the use of open data technology, and different search functions (Leston \& Thompson, 2013). In some cases, information on more than one website is provided where separate sites have been established for different chambers of the national parliament (Leston \& Thompson, 2013). This is the case in the websites of US Congress (Senate and House of Representatives); French Parliament (Senate and National Assembly); Austrian Parliament (National Council and Federal Council); Italy Parliament (Senate and Chambers of Deputies); South Africa Parliament (National Assembly and National Council of Provinces) etc.

In legislative websites' design and development, it is important for legislatures to get input from all relevant stakeholders (end users of the website) (Koroieva, Mierina, \& Karklina, 2017; Setala \& Gronlund, 2006). In the past decades, websites were considered an information platform and were unidirectional, but in contemporary times, legislative websites have become essential tools of engagement with the electorates. As Leston and Thompson (2013) notes, parliaments are encouraged to use the 'three-click rule' to ensure greater accessibility. The three-click rule suggests that users of websites should be able to locate any information with three mouse clicks or less. Web surveys (Feeney \& Welch, 2017; Leston \& Thompson, 2013; Lee, 2017) have shown that certain pages such as legislative news or list of elected representatives are extremely popular and should be promoted on the homepage to enable users retrieve required information with minimum clicks. In addition, the development and maintenance of parliamentary websites requires a good level of strategic planning and management. As the online face of the institution, it is essential that some degree of website planning is incorporated into a parliaments' general strategic plan so that its importance is recognised at the very highest level of the parliamentary administration (Setala \& Gronlund, 2006). When opportunities for citizen-representative engagement are ineffective in affecting government policy or when citizens feel that public institutions do not represent them (Oni, Oni, \& Ibietan, 2016), there is a need for innovations to re-engage citizens and relevant stakeholders through the dissemination of information services online and providing multiple channels for citizens interaction to ensure better 
accountability and representation. The successful implementation of e-government requires support from the highest level of government (The World Bank, 2017; Wamoto, 2015). This is also the case for e-parliament. In previous literatures on e-governmental websites, the emphasis has been on the executive arm of state government with little research on assessing the effectiveness of parliamentary websites of Nigerian state legislatures in providing access to information to strengthen democratic transparency and promote citizens engagement.

\section{METHODOLOGY}

A desk research methodology was employed for this review. Online and offline documents were consulted to determine the interactive tools used by all the 36 State Houses of Assembly; Official Websites, Facebook, Twitter, Instagram and YouTube pages. Also used was a manual test based on categories and key sub-factors based on IPU guidelines for parliamentary websites (Inter-Parliamentary Union, 2009). The criteria were grouped into sub-factors, website structure, social media tools, management and dissemination of legislative information, constituency activities reporting, interactivity and enhanced web tools.

\section{RESULTS AND DISCUSSION}

A comprehensive review of websites is aimed at examining the implementation level of the internet in the 36 State Houses of Assembly and their commitment towards enhancing citizens' engagement through online portals and social media. Preparatory desk research was conducted using publications, reports, websites and internal documents supplied by contact persons in the respective departments and organisations.

The official websites, Facebook and Twitter pages of the 36 state legislatures in Nigeria were reviewed. Some of the states did not have official websites while some of the web address links were dead. Majority of the states (94\%) do not have official Twitter accounts while more than half of the states have official Facebook pages. A review of the websites of 36 State Houses of Assembly is presented below under different sections.

\section{Official Websites of State Legislature}

The results shown in Figure 1 reveals that only 13 (36\%) states have official websites while the remaining 23 (64\%) states do not have official websites. While 13 State Houses of Assembly have implemented official websites, 5 (38\%) of them are active and functional with basic web features while $8(62 \%)$ are inactive with broken links. According to the findings, state legislatures have not fully understood the importance of online presence in promoting transparency to strengthen democracy and improve citizens engagement.

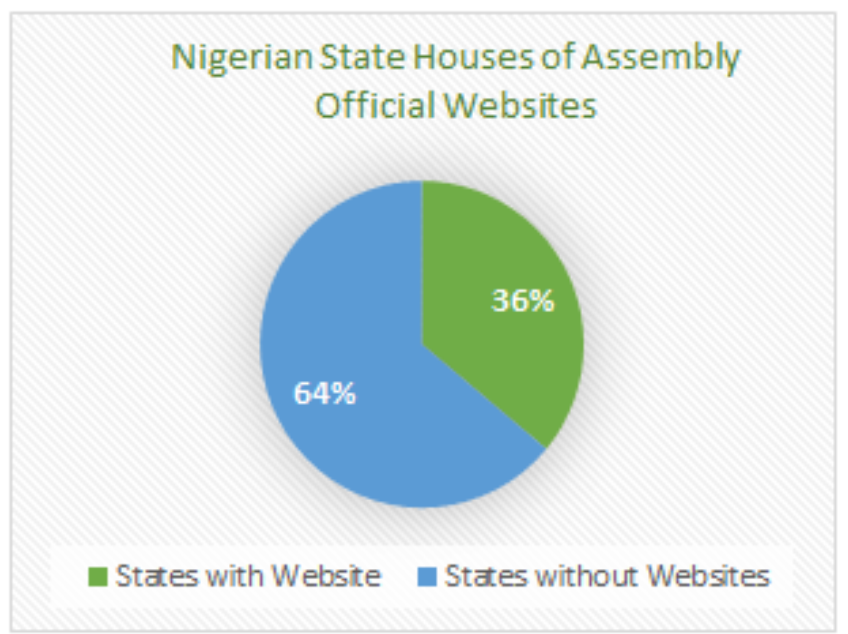

FIGURE 1. Nigerian state houses of assembly official websites

Three websites: Kano, Lagos, and Ogun, provide users with advanced features such as archiving; cloud storage; and enewsletters. Interestingly, none of the websites has an integrated search tool. Live audiovisual streaming of parliamentary plenary debates is available on the websites of Edo, Lagos, Ogun and Kano state legislatures but only functional on the website of Ogun State House of Assembly. Figures 2, 3, 4, 5 and 6 show the homepages of Edo, Kano, Lagos, Ogun and Osun State Houses of Assembly, respectively.

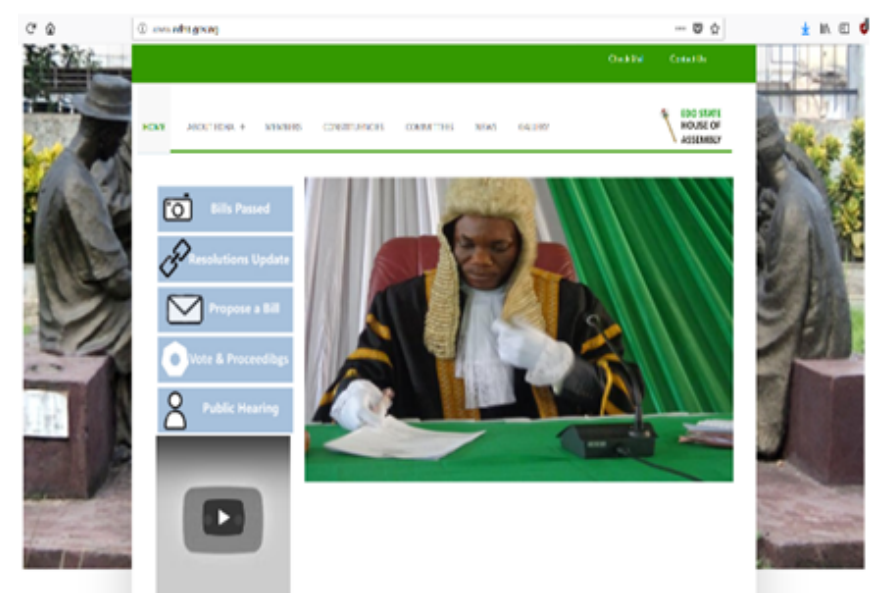

FIGURE 2. Edo state house of assembly website (https://bit $.1 y / 2 U 3 f G X q)$ 


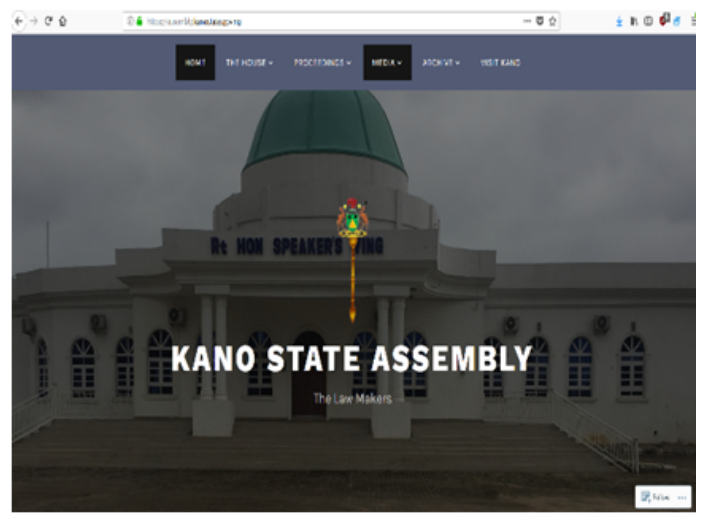

FIGURE 3. Kano state house of assembly website (https://bit.1y/2UbXKtF)

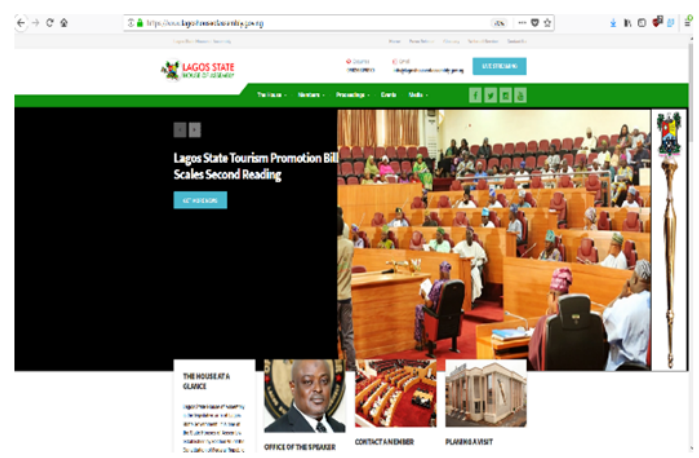

FIGURE 4. Lagos state house of assembly website (https: //bit.1y/2urIUkb)

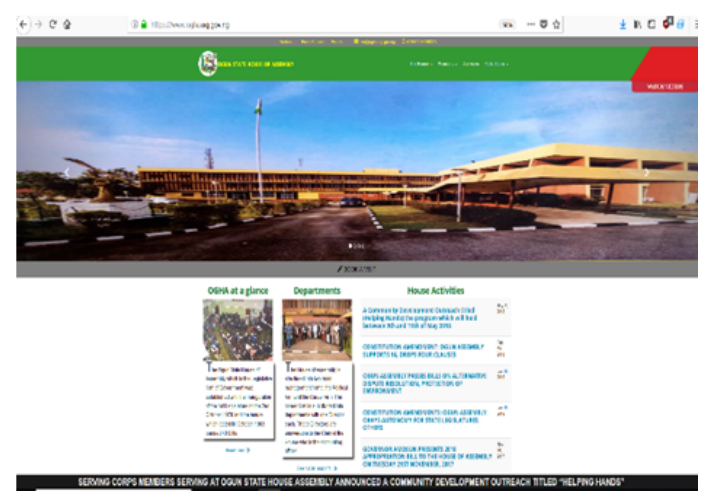

FIGURE 5. Ogun state house of assembly website (https : //bit.1y/2U77NjI)

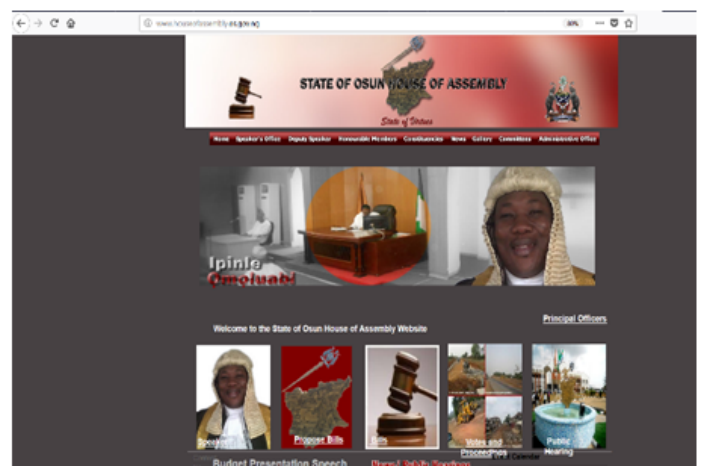

FIGURE 6. Ogun state house of assembly website (https://bit.1y/2U77NjI) 
Only the Kano State legislature website, presented in Figure 3, is secured and runs on Hypertext Transfer Protocol for secure internet connection (HTTPS).

\section{Social Media Tools}

As presented in figure 7, 21 state legislatures have official Facebook pages while only Lagos state has both a Twitter and Instagram page. About $75 \%$ of the Facebook pages of state legislatures have improved citizens' participation which is evident from the interaction of these legislatures with citizens on their Facebook pages. However, only 5 legislative websites have enhanced features for increased citizens' participation such as feedback mechanism, contact email and request for comments facility.

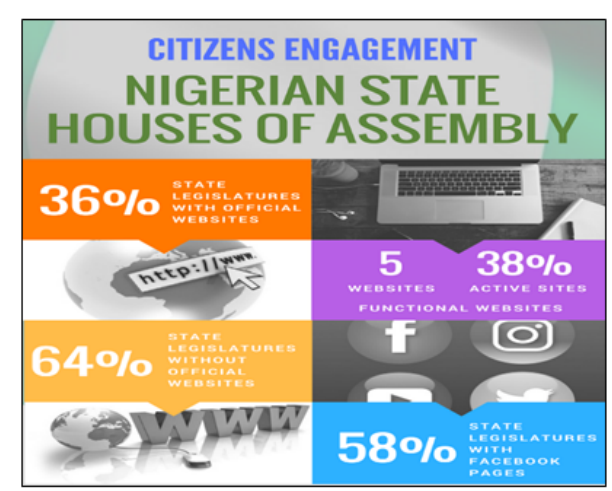

FIGURE 7. Nigerian state houses of assembly legislative tools on social media website

Additionally, the data collected also revealed that 11 (52\%) of the 21 official Facebook pages are professionally managed and regularly updated while $10(48 \%)$ are not. Lagos is the exception because it extends to twitter, that is managed and constantly updated. Also, the Facebook pages of Edo, Katsina, Kwara, Oyo, Osun, Oyo and Sokoto are not regularly updated. Facebook pages of Katsina and Sokoto provide limited coverage of legislative activities while that of Kwara is inactive. Furthermore, Borno has 2 Facebook pages, and this study was unable to confirm the official page of the state legislature.

\section{Legislative Documents and Agenda}

The Facebook page of 5 (24\%) State Houses of Assembly: Akwa-Ibom; Anambra; Bayelsa; Enugu; and Lagos cover the legislative agenda of their legislature and provide copies of legislative documents in multimedia (jpeg) formats. However, not all the legislative documents are provided, and some of the multimedia are of low quality as highlighted in the case of Anambra State.

\section{Constituency Activities}

Report of constituency activities is covered by 9 (43\%) State Houses of Assembly on their Facebook pages: Akwa-Ibom, Bayelsa, Cross River, Enugu, Gombe, Jigawa, Lagos, Niger and Ogun. Jigawa Facebook page provides constituency activities report in Hausa, the local dialect.

\section{Legislative Matters}

News and Reports on issues related to the legislature are covered by the Facebook pages of 10 (48\%) states: AkwaIbom, Anambra, Bayelsa, Cross-River, Enugu, Gombe, Jigawa, Lagos, Niger and Ogun. This indicates that coverage of legislative issues is present on less than half of the Facebook pages of all states.

\section{Electronic Media and Multimedia Content}

Anambra House of Assembly extends live video coverage and archive videos on its Facebook page while Oyo has a YouTube video link embedded on its Facebook page. The Facebook pages of Anambra, Bayelsa, Cross River, Jigawa, Lagos, Niger and Ogun (33\%) provide basic multimedia content; some of which are outdated and archival materials. Ogun supports live streaming on its website and its YouTube channel, but users can only access archive videos.

\section{Citizens Engagement: Feedback and Interactivity Tools} contact page or extends citizens engagement tools. While all MPs contact details are displayed the link to the section on constituency and representatives is broken and redirects to a different section of the website. $80 \%$ of the 5 active websites; Kano, Lagos, Ogun and Osun provide limited feedback and interactivity tools. Lagos and Ogun (10\%) extends Facebook and Twitter social media on their websites. These are regularly updated and frequently inform the electorates on the latest legislative activities, draft legislation, bill progression and budget processes.

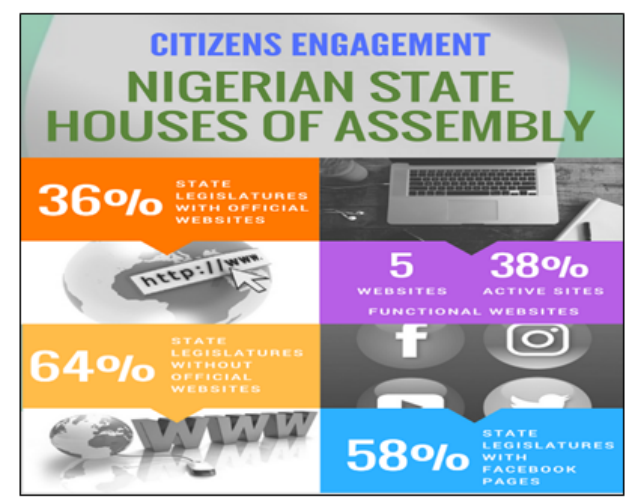

FIGURE 8. Nigerian state houses of assembly legislative tools on social media website 
From our evaluation, the findings of this research highlight the following:

- $48 \%$ of the active Official Websites and $48 \%$ of the Facebook pages were not regularly updated.

- $90 \%$ of websites did not provide access to all relevant legislative documents and verbatim reports of chamber proceedings.

- $90 \%$ of functional websites had poor archival storage system.

- $75 \%$ of state legislatures did not provide information on constituency activities.

- $70 \%$ of the activities and reports on social media was centered around the speakers of state houses of assembly with less focus on other MPs.

- $80 \%$ of the websites were deficient in terms of interactivity. There is no provision for e-petitions, e-consultations, online survey or online post.

- No active search facility provided on all the websites.

- News articles, reports and documents on $70 \%$ of the websites were not dated to assist users identify when it was uploaded.

- The websites with multimedia content were heavy and slow when loading; and lack of good contacts for feedback. - A total of 14 states (38.9\%) appear to rely only on the state government portals to provide all information on the state legislatures. However, this system does not guarantee independence of the legislature as this practice enables state government (executive) to exercise full control over information provided on the websites over which the legislature has neither ownership nor control.

Based on the research result, the researchers suggest the following recommendations which could help to address the concerns raised from the evaluation successfully:

- Design and development of a more responsive and interactive legislative website based on web heuristic principles should be incorporated into the strategic plan of state legislatures that lack an online presence.

- It is important for the legislature to determine the primary role of the website and the specific image of parliament for projection online.

- Video and multimedia content with live broadcast of public seating and educational videos on the legislature and a fully integrated search engine will help to modernize and facilitate citizens access to parliamentary information.

- Need to constantly update the websites and Facebook pages with legislative documents and activities at least 3 times a week (before the end of each legislative day) while extending to twitter. This will assure users of the website that the information is accurate and up-to-date.
- Provide access to all relevant legislative documents that are always available to users with search functionality and meta-data.

- Integrate interactivity tools and applications such as eletters, e-petitions, e-consultations, blogs and chats to encourage engagement.

- Integrate Web 3.0 tools on the website to promote interactivity, smart tags and web semantics (including XML) to enable users generate, share (download) and connect content through search and analysis based on the ability to comprehend the meaning of words.

- Developing and maintaining their official websites and online portals to enable state legislatures to take ownership of their websites.

- It is important for website content to be mobile-friendly as studies have shown that majority of citizens access online sites through web-enabled mobile devices; for faster loading speeds and compatibility. This can be achieved through code optimization.

- Provide means for constituents to contact MPs through constituency office or legislative switchboard numbers.

\section{CONCLUSION}

The world e-parliament report of 2016 highlighted some of the critical challenges confronting parliaments in effectively utilizing ICT technologies. Some of them include insufficient technical knowledge among legislative staff; limited resources for legislatures and lack of ICT infrastructure such as essential features like the internet; an intranet; computers; network devices; backup software; and digitizing systems among others.

It is evident from the outcome of this study that these challenges are confronting majority of the State Legislatures in Nigeria in addition to lack of political will. Without support from the management, innovation is less likely to be adopted as management support provides a positive environment for the implementation of e-parliament. Eparliament has the potential to enhance the internal working process of the Nigerian state legislatures and parliamentary website has the ability to strengthen democratic transparency and build interactivity with citizens.

\section{LIMITATIONS AND RECOMMENDATIONS}

The research achieved its aims but encountered some limitations. Majority of the state legislatures did not have official websites. Even at that, only a few were functional. Therefore, to fully assess the impact of online presence state legislatures on citizens' engagement, Facebook, Instagram and Twitter official accounts were included in the research. 
There is a need to extend the research to determine the distinct technical challenges for each state legislature and document the factors for their inability to implement interactive websites (online presence) fully; provide interactivity tools, feedback mechanisms and extend social media. Future research should also attempt to assess the impact of online presence and usage of social media by legislatures towards re-engaging the citizens.

\section{ACKNOWLEDGEMENT}

This paper was supported by Khazar University, Azerbaijan. National Institute for Legislative and Democratic Studies, National Assembly, Nigeria provided insight and expertise that greatly assisted the research.

\section{REFERENCES}

Alahoul, M. H. M., Azizan, N., \& Alwi, N. H. (2016). Factors that affect the use of Malaysian e-learning websites by visually impaired users in the transfer of Islamic knowledge. Journal of Advanced Research in Social Sciences and Humanities, 1(1), 30-40. doi:https://doi.org/10.26500/jarssh-01-2016-0104

Azhar, M. (2015). The concept of religious democracy as a new political philosophy for countries with moslem predominant. Journal of Advances in Humanities and Social Sciences, 1(1), 19-28. doi:https://doi.org/10.20474/jahss1.1.3

Coleman, S. (2000). Parliament in the information age: The case of westminster and holyrood. In R. Gibson and S. Ward (Eds.), Reinvigorating democracy? British politics and the Internet. Farnham, Surrey: Ashgate Pub Ltd.

Dai, X., \& Norton, P. (2007). The internet and parliamentary democracy in Europe. The Journal of Legislative Studies, 13(3), 342-353. doi:https://doi.org/10.1080/13572330701500763

Edigheji, O. (2016). Political representation in Africa: Towards a conceptual framework. Africa Development, 31(3), 93-119.

Feeney, M., \& Welch, E. (2017). Technology-task coupling: Exploring social media use and managerial perceptions of e-government. American Review of Public Administration, 46(2), 162-179. doi:https://doi.org/10.1177/ 0275074014547413

Global Centre for ICT in Parliament. (2016). 2016 world e-parliament report. Retrieved from https://bit.1y/2TZQCS3 (accessed on 15 July, 2017)

Inter-Parliamentary Union. (2009). Guidelines for parliamentary websites, united nations department of economic and social affairs, through the global centre for ICT in parliament. Retrieved from https://bit.1y/2HL4b14 (accessed on 14 March, 2017)

Koroieva, I., Mierina, I., \& Karklina, I. (2017). Small rural schools on the edge of survival: Comparative assessment of stakeholders' perspectives in Latvia and Norway. Journal of Advances in Humanities and Social Sciences, 3(4), 214-225. doi:https://doi.org/10.20474/jahss-3.4.3

Lawyer, L. A. (2017). The changing character of democracy in the pre and post colonial Cameroon: An old practice, a new word. Journal of Advanced Research in Social Sciences and Humanities, 2(1), 43-53. doi:https://doi.org/10.26500/ jarssh-02-2017-0106

Lee, J. (2017). Handbook on information technology in government, an exploratory study of e-participation technology adoption by citizens. New York, NY: Routledge.

Leston, C., Bandeira, \& Thompson, L. (2003). Using parliamentary websites as an engagement tool. Retrieved from https:// bit.1y/2UVlmzT (accessed on 13 June, 2017)

Leston, C., Bandeira, \& Thompson, L. (2013). Organising and managing parliamentary websites. Retrieved from https:// bit.1y/2Wt5Vz8 (accessed on 14 July, 2018)

Nabatchi, T., \& Leighninger, M. (2015). Public participation for 21st century democracy. New York, NY: John Wiley \& Sons.

Nkwe, N. (2012). E-government: Challenges and opportunities in Botswana. International Journal of Humanities and Social Science, 2(17), 39-48. doi:https://doi.org/10.9790/0837-1264048

Norris, P. (2001). Digital divide: Civic engagement, information poverty, and the internet worldwide. Cambridge, UK: Cambridge University Press.

Oni, A. A., Oni, S., \& Ibietan, J. (2016). ICT and democratic parliament in Africa: State of the matter. Journal of Governance and Development, 12(1), 71-85. doi:https://doi.org/10.24297/ijct.v13i6.2520

Papaloi, A. (2011). E-parliaments and novel parliament-to-citizen services. Journal of Democracy and Open Government, 3(1), 80-98. doi:https://doi.org/10.29379/jedem.v3i1.53

Salgado, S. (2016). The internet and democracy building in lusophone African countries. London, UK: Routledge. 
Setala, M., \& Gronlund, K. (2006). Parliamentary websites: Theoretical and comparative perspectives. Information Polity, 11(2), 149-162. doi:https://doi.org/10.3233/ip-2006-0095

Sriboonyaponrat, P. (2016). The implementation process of the public policy to promote and develop the quality of life of the disabled in Thailand. International Journal of Humanities, Arts and Social Sciences, 2(6), 198-202. doi:https:// doi.org/10.20469/ijhss.2.20001-6

The World Bank. (2017). World development report 2017: Governance and the law, from transparency to accountability through citizen engagement. Retrieved from https://bit.1y/2k157Pp (accessed on 14 July, 2017)

Wamoto, F. (2015). E-government implementation in Kenya, an evaluation of factors hindering or promoting e-government successful implementation. International Journal of Computer Applications Technology and Research, 4(12), 906-915. doi:https://doi.org/10.7753/ijcatr0412.1006 